\title{
Progesterone Receptor Positive by Immunohistochemistry 91-100 Percent
}

National Cancer Institute

\section{Source}

National Cancer Institute. Progesterone Receptor Positive by Immunohistochemistry 91 100 Percent. NCI Thesaurus. Code C141457.

An immunohistochemical staining finding indicating that 91-100 percent of the cells in a tissue sample are expressing progesterone receptor. 